\title{
An outbreak of gastroenteritis by Salmonella enterica subspecies diarizonae
}

\author{
RS Parihar, Archana Bora, Prabhat Kiran Khatri and Vikrant \\ Negi* \\ Assistant Professor, Department of Microbiology, GMC Haldwani, India
}

Received: 10 February, 2020

Accepted: 26 March, 2020

Published: 27 March, 2020

*Corresponding author: Vikrant Negi, M. Sc Medical Microbiology, Assistant Professor, Department of Microbiology, GMC Haldwani, India, E-mail: negi.vikrant@gmail.com

Keywords: Diarrhea; Foodborne Infections; Nontyphoidal salmonellosis

https://www.peertechz.com

\section{Abstract}

Gastroenteritis in human by Salmonella enterica subspecies diarizonae is rare and usually observed in neonates and children with history of contact with reptiles. Salmonella enterica subspecies diarizonae were isolated from two young adult male patients with symptoms of acute gastroenteritis. The isolates were identified by Vitek 2 compact system and agglutination by specific antisera. The isolates were susceptible to Amikacin, Imipenam, Cefazolin and Ceftazidime. Patient rapidly responded to Amikacin and Ceftazidime therapy. Arizona group Salmonella should be looked in cases of gastroenteritis whenever there is history of proximity with reptiles.

\section{Introduction}

Food borne diseases including, food borne intoxication and infections, are terms applied to illness acquired through the consumption of contaminated food; they are frequently and inaccurately referred to as food poisoning. The incidence becomes an outbreak only if the illness occurs within a short but variable period of time after a meal during which individuals have consumed foods in common [1]. Acute gastroenteritis caused by non-typhoidal Salmonella continues to be an important public health problem worldwide. Consumption of raw and undercooked meat, poultry eggs, and dairy products are the most common reasons for its transmission [2]. Reptileassociated salmonellosis is an emerging zoonosis in humans who handle reptiles directly or indirectly, causing mainly enteric illness. Rare cases of gastroenteritis in humans with Salmonella enterica subspecies arizonae [3] and Salmonella enterica subspecies diarizonae [4] are reported. Here we describe two cases of Salmonella enterica subspecies diarizonae gastroenteritis during a clinically suspected outbreak of gastroenteritis which occurred in a camp at Barmer district of Thar desert.

\section{Cases}

Four patients from a camp located in Gadra (Barmer) were presented on $9^{\text {th }}$ March 2017 at Government Hospital, Barmer (Rajasthan) with sudden onset of diarrhea with or without abdominal pain and vomiting. Later 12 more patients from same camp were admitted on $10^{\text {th }}$ March. The patients had a history of watery diarrhea with 10-12 motions/day and vomiting 2-5 times/day in the past 2 days. Their skin and mouth appeared dry. All the patients were male, and their age ranged between 18 and 45 years. Complete Blood Counts of all the patients were performed and found within normal range. Stool samples were sent to Microbiology Department of Dr Sampurnanand Medical College, Jodhpur on $11^{\text {th }}$ March 2017. No leftover food sample was sent for testing. All the stool samples were semi-formed in consistency with no pus, blood or worm in them. Stool samples were inoculated on MacConkey agar, Alkaline Phosphate Water (APW) and Selanite F broth. Subcultures were made on Thiosulfate citrate bile salts sucrose (TCBS) agar from APW and on Xylose lysine deoxycholate (XLD) agar from Selanite F broth after 8 hours of incubation.

Gram staining, Hanging drop motility test, Saline and Iodine mount of stool samples were also performed. Few Gramnegative bacilli were observed in Gram staining. Hanging drop motility revealed the bacteria as actively motile but the motility was not suggestive for Vibrio species. No RBCs, trophozoite, ova or cyst was observed in saline and iodine mounts. Pus cells were found in all the stool samples but were abundantly present in four samples.

No intestinal pathogen grown in 14 samples however in 2 samples non-lactose fermenting colonies (NLF) grew on 
MacConkey agar and red colonies with black centers grew in XLD medium. Both the growths of NLF colonies were further subjected to Gram staining and routine biochemical testing (triple sugar iron agar, indole, methyl red, voges proskeur, citrate, mannitol, urea and motility). Both organisms were motile gram-negative bacilli but the results were inconclusive. Further biotyping was performed which identified the organisms as Salmonella enterica. The isolates were later subjected for identification and antibiotic susceptibility testing in Vitek ${ }^{\circledR} 2$ compact (bioMérieux, Marcy-l'Étoile, France). Both isolates were identified as Salmonella enterica subspecies diarizonae with similar antibiogram pattern. They were sensitive to Amikacin, Imipenem, Cefazolin and Ceftazidime. Augmentin, Aztreonam, Ciprofloxacin and Nalidixic acid were found to be resistant. To confirm the identification, subcultures of both colonies were made on nutrient agar and incubated for 24 hours at $37^{\circ} \mathrm{C}$. Fresh growths were tested for agglutination by specific antisera (Remel Europe Ltd, Dartford, UK).

Treatment with Amikacin and Ceftazidime was started and the patients improved within 4-5 days. As the isolated pathogens are associated with reptiles, the history of contact or contamination by reptiles was looked for. The camp is located in the desert region with dry and hot climate. These areas are filled with reptiles such as snakes and lizards but no confirmed history of any contact with these reptiles was made.

\section{Discussion}

In 1939, Caldwell and Ryerson isolated Arizona group organism for the first time from reptiles in America. This organism has been called by various names such as Salmonella arizonae, Paracolobacterium arizonae, Arizona arizonae, Arizona hinshawii, etc. [5] S. enterica ssp. diarizonae is part of the normal reptile intestinal flora but can cause disease in monotremes, turkeys, chickens, goats, and rarely in humans [6]. Salmonella enterica ssp diarizonae and arizonae are the major reptile-associated pathogens in humans [7] and are highly prevalent in free-living and captive reptiles, particularly in snakes $[8,9] \mathrm{S}$. enterica ssp. diarizonae enteritis or systemic infections have been well described in patients residing in the southern states of the USA and Europe. It is much rare, with only a few cases reported in the literature [1013]. It can be difficult to identify S. enterica ssp. diarizonae due to their distinguishing biochemical features such as the ability to utilize malonate, liquefy gelatin and the inability to grow in the presence of KCN (potassium cyanide), which are generally not looked into for routine identification of bacterial isolates. Isolation of $\mathrm{S}$. enterica ssp. diarizonae from the stools is difficult as some strains ferment lactose within 48 hours (approximately 15\%) and they may be routinely discarded as non-pathogens. However, the presence of hydrogen sulfide is an important diagnostic clue during routine screening [14]. Most cases of invasive S. enterica ssp. diarizonae infection have been either in younger patients specially neonates or those with underlying diseases including collagen vascular diseases, malignancy, organ transplantation and HIV infection $[4,5,15,16]$. However, in this case both the patients were adults with no underlying diseases. The stool specimens were sent to
Microbiology two days after the onset of symptoms which may be reason for pathogens not growing in most of the specimens. The leftover food was also not available to trace the source of infection. The camp is present in Thar Desert region which is largely inhabited by reptiles such as lizards and snakes. Snakes and lizards frequently break into the compound area of the camp. Only the history of snakes and lizards contaminating that region can be associated with the isolated pathogens.

\section{Conclusion}

Incidences of Arizona group of Salmonella are rare but exist in India. S. enterica ssp. diarizonae can cause gastroenteritis in healthy adults. The laboratory should also attempt to detect Arizona group in patients with gastroenteritis and have history with proximity to reptiles.

\section{References}

1. Heymann DL (2004) Control of communicable diseases Manual. 18th ed. Vol. 211. Washington DC: American Public Health Association 469-473.

2. Thong KL, Goh YL, Radu S, Noorzaleha S, Yasin R, et al. (2002) Genetic diversity of clinical and environmental strains of Salmonella enteric serotype Weltevreden isolated in Malaysia. J Clin Microbiol 40: 2498-2503. Link: https://bit.ly/3bmgfk6

3. Mahajan RK, Khan SA, Chandel DS, Kumar N, Hans C, et al. (2003) Fatal Case of Salmonella enterica subsp. Arizonae. Gastroenteritis in an Infant with Microcephaly. J Clin Microbiol 41: 5830-5832. Link: https://bit.ly/2UDf49g

4. Hervás JA, Rosell A, Hervás D, Rubio R, Dueñas J, et al. (2012) Reptile Pets associated Salmonella enterica Subspecies diarizonae Gastroenteritis in a Neonate. Pediatric Infectious Disease Journal 31: 1102-1103. Link: https://bit.ly/3brl2Re

5. Yunsop C, Oh HK, Samuel YL, Ki SC, Toshio S (1991) Salmonella enterica subspecies diarizonae bacteremia in an infant with enteritis- $A$ case report. Yonsel Medical Journal 32: 275-278. Link: https://bit.ly/2UowqYC

6. Aiken AM, Lane C, Adak GK (2010) Risk of Salmonella infection with exposure to reptiles in England, 2004-2007. Euro Surveill 15: 19581. Link: https://bit.ly/3ayAv25

7. Pedersen K, Lassen-Nielsen AM, Nordentoft S, Hammer AS (2009) Serovars of Salmonella from captive reptiles. Zoonoses Public Health 56: 238-242. Link: https://bit.ly/2JhSRIn

8. Schröter M, Roggentin P, Hofmann J (2004) Pet snakes as a reservoir for Salmonella enterica subsp. diarizonae (Serogroup IIIb): a prospective study. Appl Environ Microbiol 70: 613-615. Link: https://bit.ly/2Jfc7GF

9. Centers for Disease Control and Prevention (CDC) (2003) Reptileassociated salmonellosis - selected states, 1998-2002. MMWR Morb Morta Wkly Rep 52: 1206-1209. Link: https://bit.ly/2yctllG

10. Casner PR, Zuckerman MJ (1990) Salmonella arizonae in patients with AIDS along the U.S.-Mexican border. N Engl J Med 323: 198-199. Link: https://bit.ly/2JhSWf9

11. Schneider L, Ehlinger M, Stanchina C, Giacomelli MC, Gicquel $P$, et al (2009) Salmonella enterica subsp. arizonae bone and joints sepsis. A case report and literature review. Orthop Traumatol Surg Res 95: 237-242. Link: https://bit.ly/2JkZYA2

12. Starakis I, Siagris D, Karatza C, Solomou H, Bassaris H (2007) Endocarditis due to Salmonella enterica subsp. arizonae in a patient with sickle cell disease: a case report and review of the literature. Cardiovasc Hematol Disord Drug Targets 7: 199-204. Link: https://bit.ly/39ohDRU

Citation: Parihar RS, Bora A, Khatri PK, Negi V (2020) An outbreak of gastroenteritis by Salmonella enterica subspecies diarizonae. Arch Clin Gastroenterol 6(1): 010 
13. Editorial team Collective, Bertrand S, Rimhanen-Finne R, Weill FX, Rabsch W, et al. (2008) Salmonella infections associated with reptiles: the current situation in Europe. Euro Surveill 13: 18902. Link: https://bit.ly/3anyFRh

14. The Enterobacteriaceae. In: Winn W, Allen SD, Allen S, Janda W, Koneman EW et al. (2006) Koneman's Color Atlas and Textbook of Diagnostic Microbiology. 6th edition. Baltimore: Lippincott Williams \& Wilkins 211-300. Link: https://amzn.to/2JfYruL
15. Carmen Ferreras MD, Muñioz M, Pérez V, Benavides J, Pariente CG, et al (2007) Unilateral orchitis and epididymitis caused by Salmonella enterica subspecies diarizonae infection in a ram. J Vet Diagn Invest 19: 194-197. Link: https://bit.ly/2UmHzsF

16. Hoag JB, Sessler CN (2005) A comprehensive review of disseminated Salmonella Arizona infection with an illustrative case presentation. South Med J 98: 1123-1129. Link: https://bit.ly/2JfcD7z

\section{Discover a bigger Impact and Visibility of your article publication with}

\section{Peertechz Publications}

\section{Highlights}

* Signatory publisher of ORCID

* Signatory Publisher of DORA (San Francisco Declaration on Research Assessment)

* Articles archived in worlds' renowned service providers such as Portico, CNKI, AGRIS, TDNet, Base (Bielefeld University Library), CrossRef, Scilit, J-Gate etc.

* Journals indexed in ICMJE, SHERPA/ROMEO, Google Scholar etc.

* OAI-PMH (Open Archives Initiative Protocol for Metadata Harvesting)

* Dedicated Editorial Board for every journal

* Accurate and rapid peer-review process

* Increased citations of published articles through promotions

* Reduced timeline for article publication

Submit your articles and experience a new surge in publication services (https://www.peertechz.com/submission).

Peertechz journals wishes everlasting success in your every endeavours

Copyright: @ 2020 Parihar RS, et al. This is an open-access article distributed under the terms of the Creative Commons Attribution License, which permits unrestricted use distribution, and $r$ eproduction in any medium, provided the original author and source are credited. 